\title{
Sanitation, human rights, and disaster management
}

Article

Accepted Version

Aronsson-Storrier, M. (2017) Sanitation, human rights, and disaster management. Disaster Prevention and Management, 26 (5). pp. 514-525. ISSN 0965-3562 doi:

https://doi.org/10.1108/DPM-02-2017-0032 Available at https://centaur.reading.ac.uk/72746/

It is advisable to refer to the publisher's version if you intend to cite from the work. See Guidance on citing.

To link to this article DOI: http://dx.doi.org/10.1108/DPM-02-2017-0032

Publisher: Emerald Publishing

All outputs in CentAUR are protected by Intellectual Property Rights law, including copyright law. Copyright and IPR is retained by the creators or other copyright holders. Terms and conditions for use of this material are defined in the End User Agreement.

\section{www.reading.ac.uk/centaur}

\section{CentAUR}

Central Archive at the University of Reading

Reading's research outputs online 


\section{Sanitation, Human Rights, and Disaster Management}

\section{Introduction}

Sanitation is one of the key challenges of our time. Every day, a lack of adequate sanitation creates immeasurable suffering, primarily through the spread of disease via water, land or insects. Sanitation problems contribute to, and are exacerbated by, disasters.

Despite much interesting work being done in other fields, international legal scholars have thus far been remarkably silent on issues of sanitation. A few important exceptions exist, including Keri Ellis and Loretta Feris (2014), Catarina de Albuquerque (2014), Léo Heller (2015) and Inga Winkler (2016). Further, following the recognition by the United Nations General Assembly (UNGA) of the human right to sanitation as a separate right in 2015 , legal attention is likely to increase.

International human rights law (IHRL) is recognised as a key component of emerging international law on disaster management (see, e.g., ILC, 2016; IASC, 2011; Sphere Project, 2011; Cedervall Lauta, 2016; Cubie, 2014; da Costa and Pospieszna, 2015; Kälin, 2011). The importance of IHRL was most recently acknowledged in the International Law Commission's (ILC) Draft Articles on the Protection of Persons in the Event of Disasters (ILC Draft Articles), adopted by the ILC on second reading in June 2016. Still, while States now have embraced a human rights based approach to disaster management, significant question marks remain as to what these obligations mean in the disaster context. This article addresses this issue by exploring what these obligations mean in relation to sanitation, which in itself is a significantly underexplored aspect of IHRL.

A few limitations should be noted. First of all, the analysis in this article is focused on disasters caused by natural and human-made hazards, while excluding armed conflicts. Secondly, although acknowledging the importance of various kinds of actors in relation to sanitation, human rights, and disaster management, the analysis in this article focuses on the obligations of States as the primary duty bearers. Thirdly, the purpose of this article is not to analyse non-legal debates around best practices around sanitation, but rather to tie together aspects of legal instruments and debates so as to illuminate existing legal obligations for States in relation to sanitation and human rights in the disaster management context. Such analysis is vital from an international law perspective, as the lack of clarity and the absence of scholarly engagement around the legal aspects of sanitation leave too much of the fulfilment of needs in the hands of relief or development organisations, while limited attention is paid to existing obligations upon States. Fourthly, this article does not engage with accountability mechanisms and challenges. However, one of the key aspects of accountability is to "clarify the exact rights and obligations at play in disaster settings" (Cubie and Hesselman, 2015), which is a key aim of this article.

The next section clarifies the definition of sanitation for the purpose of this paper and introduces the contemporary challenges in relation to sanitation. Section 3 then introduces the relevant human rights framework, in particular, the development and legal status of the human right to sanitation, and the role of sanitation within other relevant rights. Following this, section 4 introduces the role of IHRL within disaster management from the perspective of State obligations, before section 5 explores human rights obligations in relation to sanitation in the different phases of disaster management. 


\section{The concept of sanitation and contemporary challenges}

\subsection{Defining sanitation}

Although many would connect "sanitation" primarily with the immediate removal of excreta, the concept is much broader. In her role as independent expert on the issue of human rights obligations related to access to safe drinking water and sanitation, Catarina de Albuquerque defined sanitation "as a system for the collection, transport, treatment and disposal or reuse of human excreta and associated hygiene" and stated that "States must ensure without discrimination that everyone has physical and economic access to sanitation, in all spheres of life, which is safe, hygienic, secure, socially and culturally acceptable, provides privacy and ensures dignity" (de Albuquerque, 2009, para 63). In providing this definition, de Albuquerque also clarified that the definition includes "domestic wastewater, which flows from toilets, sinks and showers ... insofar as water regularly contains human excreta and the byproducts of the associated hygiene" and "that, in some places, existing solutions for human excreta management make it inseparable from solid waste management" (de Albuquerque, 2009, para 63 footnote 87). This definition of sanitation in the context of human rights has been endorsed by the Committee on Economic, Social and Cultural Rights (CESCR) (CESCR, 2010, para 8) and is the one used in this article.

\subsection{Contemporary Challenges}

As of 2015, close to a billion people were defecating in the open, and an estimated 2.4 billion people did not have access to improved sanitation facilities (UN, 2015, 9). The problem is most prevalent in developing countries where 80 per cent of sewage is discharged directly into water sources without treatment (UN-Water, 2013), polluting both surface water and groundwater. The latter is particularly concerning considering the difficulty of cleaning up this important source of water underground and the rapidly diminishing groundwater supply. It should be noted that issues around wastewater treatment and water contamination do not solely relate to sanitation, but also include industrial waste (for further analysis, see Aronsson-Storrier and Salama, 2016). That said; wastewater treatment is a core part of sanitation where waterborne sanitation systems are used.

As established by the World Health Organization (WHO), a lack of adequate sanitation, leading to "[t]he discharge of untreated wastewater and excreta into the environment", has a number of negative effects on human health through the pollution of water used for drinking or bathing, the "[e]ntry into the food chain", and the provision of "breeding sites for flies and insects that spread diseases" (WHO et. al., 2008, para 2). Perhaps most importantly, water contaminated by sewage constitutes a daily and severe danger for billions of people through the spreading of waterborne diseases. In 2015, WHO estimated that the annual death toll due to diarrhoea caused by poor sanitation - leaving aside other related causes - was 280000 persons, that is, about one person every two minutes (WHO, 2015). This number notably does not include deaths from other sanitation related diseases. Further to the deaths caused by diarrhoea, millions of children, as well as many adults, also suffer from other diseases due to poor sanitation, such as cholera, worm infestations, schistosomiasis, trachoma and polio (WHO, 2015).

The diseases mentioned above do not only cause immense suffering, but they also bear with them severe consequences for education and development and thus 
increase vulnerability amongst those already marginalised (UNICEF, 2015 (I)). Despite this, sanitation receives considerably less attention and resources than water supply, even in areas where it significantly affects the quality of water. The neglect of sanitation was evident in the evaluation of the Millennium Development Goals (MDGs), in 2015, where progress relating to "access to sanitation" lagged far behind that for "access to water" (UN, 2015. See also Aronsson-Storrier and Salama, 2016).

Even where sanitation efforts are made, they often fail to protect the most vulnerable. People living in informal settlements are not only not included in sanitation efforts, but "[s]uch settlements are often situated along riverbanks or lowlying land where polluted water tends to accumulate, thereby exposing dwellers to contamination" (Zimmer et al., 2014, 341). This means that in situations where the sanitation effort for other parts of the population is waterborne, but without a complete sanitation cycle, the pollution is likely to increase rather than decrease for informal settlers. In other words, when the efforts fail properly to address the most vulnerable, their vulnerability - and suffering - will increase.

\subsection{Sanitation in disasters}

The provision of sufficient sanitation is particularly challenging in relation to disaster situations. First of all, a hazard such as an earthquake or a flood can cause existing sanitation systems to become damaged or collapse, or a drought can cause a waterborne sanitation system to become dysfunctional. Secondly, displaced persons living in camps, shelters and other kinds of temporary housing are particularly vulnerable to the spread of disease as they often live in close proximity with one another. It is essential to provide them with sanitation facilities that are accessible and safe to use in order to curb disease outbreaks.

The dangers of failing to account for sanitation in the event of a disaster are evident in the cholera epidemic that followed the devastating earthquake in Haiti in 2010. As of August 2016, the epidemic has infected at least 770,000 people and claimed more than 9,200 lives (Sidder, 2016). The outbreak was caused by poor procedures and unsound sanitation practices amongst UN peacekeepers, and spread rapidly due to a lack of proper sanitation systems for the wider population. More specifically, the outbreak was initiated by untreated, contaminated, faeces being released into the Meille River from a camp of Nepalese UN peacekeepers who had arrived in Haiti in October 2010 to assist with the post-earthquake reconstruction, shortly after outbreaks of cholera had been recorded in Nepal (Katz, 2013, 230).

The spread of the disease worsened due to the absence of adequate sanitation systems and lack of access to clean water for the Haitian population, many of whom were instead dependent on the Meille River and the attached Artibonite River, which provides water to an estimated 1.5 million people (e.g., Freedman and Lemay-Heber, $2015,8)$. It has been established that "[t]he rapid diffusion of the disease is tied to squalid conditions and insufficient health and sanitary infrastructure in earthquakeravaged Haiti" (Sidder, 2016).

The UN has been widely criticized not only for failing to prevent or stop the outbreak, but also for its long lasting failure to assume responsibility and for not ensuring reparations for victims (e.g., Freedman, 2014; Alston, 2016). An attempt to hold UN accountable before a United States (US) Court was rejected by the US Second Circuit Court of Appeals in August 2016 (Georges v United Nations, 2d Cir., 2016). Still, on 1 December 2016 UN Secretary General Ban Ki-moon apologised to the Haitian people and acknowledged that the UN "simply did not do enough with regard to the cholera outbreak and its spread in Haiti". Notably, however, the steps forward 
outlined by Ban Ki-moon, while including support to victims through a voluntary trust fund, did not include any language about compensation (UN, 2016). It should be noted that as of June 2017, the UN's responsibility for the cholera outbreak is yet again put before a US Court; this time the District Court of the Eastern District of New York (LaVenture, et al. v United Nations, et al., E.D.N.Y, 2017). As the time of writing it is still unknown if and how this case will proceed.

The issue of sanitation was also high on the agenda following the earthquakes in Nepal on 25 April and 12 May 2015. The earthquakes reportedly destroyed close to 5 200 sanitation facilities and water supply systems, as well as 220000 household toilets, thus significantly damaging development progress and bringing back open defecation in places where it previously had been eradicated (Narang, 2016; UNICEF, 2015(II)).

A 2016 study found that following the Nepal earthquakes, 57 per cent of affected children were studying in schools without sanitation facilities, and 27 per cent had experienced an "increased frequency of diarrhoea" (UNICEF et al., 2016, 1). The study also found that the damaged sanitation facilities and lack of personal space in particularly affected women and adolescent girls, especially when menstruating (UNICEF et al., 2016, 1 and 21).

The above illustrates the importance of accounting for sanitation at all stages of disaster management, as well as to integrate sanitation efforts into other areas such as construction and education. The need for a more integrated approach to sanitation is further clear when considered through a human rights lens.

\section{Sanitation and international human rights law}

Although not recognised as a human right in itself until recently, adequate sanitation is vital for the fulfilment of a number of human rights obligations. As one of the key contributors to water contamination, sanitation affects not only the right to access safe water and the right to sanitation, but also the right to life, health, housing, food, and education (CESCR, 2003, para 3; Winkler, 2016, 24).

There is not space here to detail the role of sanitation in relation to all relevant human rights, however, considering its strong standing in human rights law, it is important to consider sanitation through the lens of the right to life, which is protected under Article 6 of the International Covenant on Civil and Political Rights (ICCPR).

The right to life does not only pose obligations upon States to avoid unlawful killings, but it also requires States to take positive measures in order to prevent the loss of life. That the right to life imposes such positive obligations upon States finds support in the wording of Article 2(1) of the ICCPR, requiring States "to respect", as well as "to ensure to all individuals within its territory and subject to its jurisdiction the rights recognized in the present Covenant". Such an interpretation of States' obligations has further been supported by regional human rights courts, including the European Court of Human Rights (ECtHR) (e.g. in Öneryildiz v Turkey, ECtHR, 2004 and Budayeva and Others $v$ Russia ECtHR, 2008) and the Inter-American Court of Human Rights (e.g. in Villagran Morales et al v Guatemala, IACtHR,1999). A reading of the right to life as creating positive obligations for states has also been supported by the UN Human Rights Committee (2004, para 6).

Although human rights courts are yet to explore the right to life in relation to sanitation, there is little doubt that an obligation exists which, at the very least, requires states to provide such sanitation services that it prevents casualties from diseases that result directly from poor sanitation. This is also supported by the CESCR, which, in relation to the right to water has stated as one of the "core 
obligations" "[t]o take measures to prevent, treat and control diseases linked to water, in particular ensuring access to adequate sanitation" (CESCR, 2003, para 37(i)). In other words, States have a legal responsibility to prevent fatalities stemming from a lack of adequate sanitation.

\subsection{The human right to sanitation}

The human right to sanitation "requires services to be available, safe, acceptable, accessible and affordable" (Heller, 2015, para 5). As discussed above in section 2.2, the right to sanitation moves far beyond the mere provision of sanitary facilities and includes a complete sanitation system. The all-encompassing definition of sanitation in the human rights context is highly significant when considering the role of sanitation in thwarting disease outbreaks.

Despite being part of the development discourse for decades (e.g., 1972 Stockholm Declaration on the Human Environment, para 3 and principle 2; UNGA 1980; 1992 Rio Declaration on Environment and Development; Plan of Implementation of the World Summit on Sustainable Development 2002, para 8; Millennium Development Goals, Goal 7(c)), the right to sanitation was for long not expressly included in general IHRL instruments (although the importance of sanitation was acknowledged in the Convention on the Elimination of All Forms of Discrimination against Women, Article 14(2)(h) and the Convention on the Rights of the Child, Article 24(2)(e)). A key turning point occurred in 2003, when the CESCR adopted its General Comment 15, The right to water (Arts. 11 and 12 of the Covenant). While not directly referring to a right to sanitation, the CESCR held sanitation to be a vital part in addressing water quality in preventing the spread of disease (para 37(i)).

Seven years later the UNGA adopted its Resolution on the Right to Water and Sanitation, positioning the right under Article 11(1) of the International Covenant on Economic, Social and Cultural Rights (ICESCR) (UNGA, 2010). Even though resolutions by the UNGA do not in themselves impose binding legal obligations upon States, they are highly significant as evidence of how States interpret existing rules of international law, in this case, Article 11(1) of the ICESCR. Further, UNGA resolutions, as well as other non-binding guidelines and standards commonly used to regulate both human rights and disaster management, are helpful tools of interpretation for States, as well as non-State actors, through their promotion of a normative framework and consensus around obligations as well as the use of terms. This was recently highlighted by a number of states in the debate around the ILC Draft Articles in the UNGA Six th Committee (UNGA Sixth Committee, 2016).

A critical step, the 2010 Resolution has still been criticised for merging water and sanitation into one right, thus veiling their significant differences (see, e.g., Ellis and Feris, 2014; Winkler, 2016). In line with this critique, the separate rights to water and sanitation were acknowledged by the UNGA in December 2015 (UNGA, 2016). That said, the right to sanitation is still closely linked to the right to water. First of all, a large portion of sanitation systems, especially in the developed world, are reliant upon water and thus affect the quantity of water needed to meet basic needs. Secondly, inadequate sanitation can lead to contamination of freshwater, thus making it unsafe to consume. Unfortunately, if water security has been discussed to a limited extent in international legal discourse, sanitation has thus far been close to invisible.

\section{The role of international human rights law in disaster management}

It is increasingly acknowledged that disasters do not exist in a legal vacuum, but that (pre)existing rules and obligations continue to apply in disaster situations. This 
includes rules under IHRL (see, e.g., Cedervall Lauta, 2016). The benefits of taking a human rights based approach to disaster management have been widely acknowledged, as leading to persons affected by a disaster being considered "individual rights holders who can claim rights from particular duty bearers rather than ... passive beneficiaries and recipients of charity" (IASC, 2011, 2. See also UNHRC, 2015, para 82). It is, however, not always clear how IHRL rules are to be interpreted in the disaster context. First of all, it should be remembered that the affected State has the primary responsibility to care for its citizens in the event of a disaster. This obligation extends not only to the State's citizens, but to all persons on its territory (Article 2(1) ICCPR: Article 2(2) ICESCR. It should be noted that Article 2(2) ICESCR allows for some scope of discrepancy between nationals and nonnationals as concerns certain benefits (CESCR, 2009), but these exceptions are not relevant for sanitation and will thus not be elaborated upon here.

It is also widely recognized that disaster management measures should be guided by human rights and the principle of human dignity. This was most recently made clear in the ILC Draft Articles, with Draft Article 4 calling for the respect for and protection of human dignity, and Draft Article 5 stating that "[p]ersons affected by disasters are entitled to the respect for and protection of their human rights in accordance with international law". Despite the wide agreement that human rights should be "respected and protected" in the event of disasters, it is less clear what this means in terms of substantial rights, as well as with regard to responsibility and accountability.

First of all, there are specific derogations and limitations built into international human rights agreements, which will have to be taken into account. According to Article 4 of ICCPR, a State can derogate from certain human rights in "time of public emergency" as long as the emergency is "officially proclaimed" and the derogations are "strictly required by the exigencies of the situation" and applied in a nondiscriminatory manner. Although a very interesting discussion in itself, it will not be elaborated upon here as it does not affect any of the rights discussed in this article (the right to life may not be derogated from as per Article 4(2) ICCPR).

Secondly, States are under an obligation to progressively realize the rights set out in the ICESCR, and "to take steps ... to the maximum of its available resources, with a view to achieving progressively the full realization of the rights in the present Covenant by all appropriate means..." (Article 2(1) ICESCR). That the rights are to be progressively realized, however, speaks to the full realization of the rights and does not relieve the states from their "core obligations", out of which access to basic sanitation has been held to be one (CESCR, 2003). In addition, as part of the progressive realization, and in accordance with the principle of non-regression, States may not take regressive steps resulting in depriving people of rights they previously have enjoyed unless such measures are justified (CESCR, 1991, para 9). In the disaster context, some regressions may be justified, particularly in the initial relief stage. Still, the ILC Draft Articles suggest that in the context of a disaster, economic, social and cultural rights should at the very least be protected in line with their core obligations (Draft Article 5, commentary para 6). Indeed, the ILC expresses a duty for the State to take active steps to ensure the "satisfaction of individual needs" and that the measures required include "the prevention and avoidance of conditions that might lead to the violation of human rights" (Draft Article 5, commentary para 4).

Importantly, Draft Article 6 recognises the importance of "taking into account the needs of the particularly vulnerable". It is clarified that this includes both groups and individuals. The commentary makes special mention of women and girls (Draft 
Article 6, commentary para 9), but also refers to Article 4(3)(a) of the Guidelines for the Domestic Facilitation and Regulation of International Disaster Relief and Initial Recovery Assistance, which includes as vulnerable groups "children, displaced persons, the elderly, persons with disabilities, and persons living with HIV and other debilitating illnesses" (Draft Article 6, commentary para 7. See also, Convention on the Rights of Persons with Disabilities, Article 11; UN Human Rights Council (UNHRC), 2015, para 101; Crock, 2016).

Of the essence here is the principle of non-discrimination (Article 2(2) ICESCR), which prohibits any discrimination of vulnerable and marginalized persons. As noted by Phan and Winkler in relation to water security, IHRL "requires states to identify, consult, and target those at greatest disadvantage" when assessing and addressing access to essentials in the context of disasters (Phan and Winkler, 2016, 315. See also CESCR, 2009; CESCR 2003, para 8).

The approach taken in the ILC Draft Articles discussed above, when read together with the core obligations identified by CESCR, is well aligned with the obligations under the 2011 IASC Operational Guidelines On The Protection Of Persons In Situations Of Natural Disasters (IASC Guidelines). The IASC Guidelines, together with, especially, the 2011 Sphere Handbook: Humanitarian Charter and Minimum Standards in Disaster Response (Sphere Handbook) (Sphere Project, 2011) have explicitly sought to translate existing human rights law into a disaster context for humanitarian personnel. Although not explicitly focused on States, but rather on various humanitarian relief organizations, it is argued here that their interpretations provide a good, albeit not perfect, starting point for interpreting human rights obligations in the disaster context. The IASC Guidelines carry particular weight since IASC is a UN agency, whose mandate stems from UNGA Resolution 46/182 (UNGA, 1991).

IHRL is also a core part of disaster risk reduction (DRR), the law and policy of which is in a period of significant development. Although DRR as an area of international law it is still in its infancy, important steps have been taken over the past few decades with non-binding instruments such as the UN General Assembly declaring in 1990 the International Decade for Disaster Reduction; the 1994 Yokohama Strategy for a Safer World: Guidelines for Natural Disaster Prevention, Preparedness and Mitigation and Plan of Action; the 2005-2015 Hyogo Framework for Action; and the Sendai Framework for Disaster Risk Reduction 2015-2030 (SFDRR) (for an overview of the extensive relevant state practice, see ILC Draft Articles, Draft Article 9, commentary para 5). The ILC Draft Articles, while stating that "[e]ach State shall reduce the risk of disasters by taking appropriate measures, including through legislation and regulations, to prevent, mitigate, and prepare for disasters" (Draft Article 9), explicitly draws upon IHRL and "the obligations undertaken by states to respect and protect human rights, in particular the right to life". (Draft Article 9, commentary para 4) It is further clarified by the ILC that "protection entails a positive obligation on States to take the necessary and appropriate measures to prevent harm from impending disasters" (Draft Article 9, commentary para 4$)$.

Draft Article 9 finds support in the case law of the ECtHR. For example, in the Budayeva case the ECtHR considered the failure to take sufficient preventative measures against the loss of eight lives due to a burst dam caused by a mudslide to be a breach of the right to life (para 158). Although the Court did not go as far as to say that the Russian authorities were under an obligation to repair the mud dam - which had been damaged the previous year - the authorities were under an obligation to 
provide a good early warning system and evacuation procedures to protect the right to life, since they were well aware of the risk (paras 152, 154 and 156). The reasoning was based on a margin of appreciation by states as to how they wish to respect, protect and fulfil human rights, in this case, the right to life (para 156. For further analysis, see Cedervall Lauta, 2016).

\section{Addressing sanitation in disaster management through a human rights lens}

A human rights based approach to sanitation requires action on all stages of disaster management, including prevention, mitigation, preparedness, response and recovery. The stages are addressed in turn below.

\subsection{Prevention and mitigation}

In relation to prevention and mitigation, the most significant contribution of sanitation is preventing and mitigating disease outbreaks, epidemics and pandemics. The explicit wording of the SFDRR, arguably the most significant DRR agreement to date, makes no mentioning of sanitation, which is remarkable considering the importance of sanitation in relation to DRR. Still, the very purpose of the Framework makes it clear that efforts need to minimize vulnerability more generally, and to build resilience against pandemics and epidemics (para 6).

Further, one of the seven targets in the SFDRR is to "[s]ubstantially reduce disaster damage to critical infrastructure and disruption of basic services, among them health and educational facilities, including through developing their resilience by 2030" (para 17(d)). The Framework further holds that States, at the national and local level, are required to " $[\mathrm{p}]$ romote the resilience of new and existing critical infrastructure, including water ... to ensure that they remain safe, effective and operational during and after disasters" (para 33(c)). There is little doubt that sanitation systems, even as separate from water systems, are included in the category of critical infrastructure. It is further clear that insufficient sanitation systems cannot only result in disaster, but disasters caused by other natural and human-made hazards, can lead to the destruction of sanitation systems.

In relation to the human right to sanitation, the respect and protection of this right would involve increasing the existence and resilience of sanitary facilities and systems and minimizing the risk for the spread of disease, thus preventing and mitigating the risk of epidemics and pandemics. Further, the right to life, while not reaching as far in terms of sanitation systems, still requires basic hygiene and sanitation measures to be taken in order to prevent deaths from disease outbreaks, in particular when an affected State has knowledge of the risk (see, eg, Budayeva and others $v$ Russia, ECtHR, 2008).

It should also be noted that other mitigation efforts, such as urban infrastructure and building codes, are closely linked to human rights and sanitation. This was, for example, seen in the aftermath of the 2015 earthquakes in Nepal, where non-resilient buildings did not only cause direct casualties and injuries, but also led to the destruction of thousands of toilets, thus destroying previously made progress against open defecation (UNICEF, 2015(II)).

\subsection{Preparedness and relief}

The strongest legal case linking human rights, sanitation, and disaster management is in the preparedness and relief phases. This is not only what most of the non-binding disaster management instruments have been concerned with, but when acknowledging the obligation to take positive measures in order to prevent human rights abuses in 
relation to disasters, the ECtHR has mainly focused on preparedness, including early warning systems.

In relation to sanitation, currently existing guidelines were written before the separate rights to water and sanitation were acknowledged by the UNGA, and so the right to water and sanitation is dealt with as one right. Despite this, they do provide some helpful guidance as to how the right to sanitation should be interpreted in the disaster context. The Sphere Handbook clarifies that the human right to water and sanitation in the event of a disaster include a right to sufficient, safe, acceptable, physically accessible and affordable water for personal and domestic uses and accessible sanitation facilities (Sphere Project, 2011, 83). The IASC Guidelines provides a similar formulation, but also add that "[a]t a minimum, safe water should be provided in a quantity that is necessary to prevent hydration; and to provide for consumption, cooking, and personal and hygienic requirements necessary for a life in dignity" (IASC, 2011, 33). The CESCR has not yet established core obligations for the right to sanitation, however, in its comment on the right to water, it included as a core obligation " $[\mathrm{t}] \mathrm{o}$ take measures to prevent, treat and control diseases linked to water, in particular ensuring access to adequate sanitation" (CESCR, 2003, para 37(i)).

One significant challenge in relation to sanitation in the aftermath of a disaster is that of the availability, safety and accessibility of facilities. This is of particular concern for vulnerable groups, including persons with disabilities, women and girls (see, e.g., UNHRC, 2015). The respect and protection of the human rights relating to sanitation in the disaster context include accessibility for persons with disabilities and sufficient lighting allowing everyone, including women, children and the elderly, safely to use the facilities without risk of violence. In order to ensure that preparedness measures are functional and will reach those in need, the IASC Guidelines propose to "[i]nclud[e] representatives of affected populations", including vulnerable groups, when designing camps and shelters. It is specifically suggested that this is done in relation to access to and location of sanitation facilities (IASC, 2011, 21).

As discussed above (section 2.3), one key issue in relation to sanitation in the aftermath of a disaster concerns displaced people, living either in provided shelters and camps, in other temporary accommodation, or on the street. Preparedness efforts need to include not only adequate sanitation facilities in camps, but also be inclusive of everyone in need regardless of where they are living. Persons living in camps, as well as persons who cannot fit into the camps and are left to live on the street, or who choose to stay in what remains of their homes where the toilet has been destroyed, are at once very vulnerable to disease while also helping to spread it. In this way, we are reminded again of the importance of including the most vulnerable and marginalized in sanitation efforts, as required under IHRL.

\subsection{Recovery and rebuilding}

Sanitation also needs to be accounted for in the recovery phase of a disaster. Not only is "build back better" a core aim of the SFDRR, but in accordance with the progressive realisation of human rights under the ICESCR discussed in Section 4, States have obligations to move beyond the respect and protection of human rights as they recover (see also, e.g., Phan and Winkler, 2016, 314). In other words, the recovery of the State and its economy must benefit its population in a way that is guided by IHRL. 


\section{Conclusion}

Even though it is widely acknowledged that IHRL continues to apply in disaster situations, there are still significant uncertainties as to how IHRL rules are to be interpreted and applied in the disaster context. The discussion above has sought to address this issue by linking previous work on human rights and sanitation to disaster management. States are required to respect and protect human rights in all stages of disasters. Although it might be justified for states not to completely fulfill the right to sanitation under certain circumstances, States must always provide at the very least their core obligations under the ICESCR, including provision of basic sanitation. States must also take positive action in order to prevent the loss of life from inadequate sanitation.

While States do not always fulfill their obligations under IHRL, and it would be naïve to think that the very existence of human rights obligations would in and of themselves ensure the respect for and protection of rights, knowing what these obligations entail in the disaster context strengthens human rights as an important tool for advocacy, accountability, and protection. Despite its limitations, a human rightsbased approach to sanitation in disaster management can assist in building resilience as well as preparation and execution of relief efforts, while focusing on the persons who need it the most and providing at least the minimum level of protection for all. 


\section{References}

Alston, P. (2016), "Report of the Special Rapporteur on extreme poverty and human rights", UN Doc. A/71/40823 (advance unedited version), 26 August.

Aronsson-Storrier, M. and Salama, H. "Tackling water contamination: development, human rights and disaster risk reduction", in Breau, S. and Samuel, K. (Eds.),

Research Handbook on Disasters and International Law, Edward Elgar, Cheltenham, UK), pp. 319-335.

Budayeva and Others v Russia (2008) App no 15339/02 \& Ors (ECtHR, 20 March 2008).

Case concerning Pulp Mills on the River Uruguay (Argentina v Uruguay) ICJ Rep 2010, 14 (ICJ, 20 April 2010).

UN Committee on Economic, Social and Cultural Rights (1990), "General Comment No. 3: The Nature of States Parties' Obligations (Art. 2, Para. 1, of the Covenant) UN Doc. E/1991/23, 14 December.

UN Committee on Economic, Social and Cultural Rights (2003). "General Comment 15, The right to water (Arts. 11 and 12 of the Covenant)". UN Doc. E/C.12/2002/11, 20 January.

UN Committee on Economic, Social and Cultural Rights (2009), "General Comment No. 20, Non-discrimination in economic, social and cultural rights (art. 2, para. 2, of the International Covenant on Economic, Social and Cultural Rights)" UN Doc. E/C.12/GC/20, 2 July.

UN Committee on Economic, Social and Cultural Rights (2010), "Statement on the right to sanitation", UN Doc. E/C.12/2010.1. (advace unedited version), 19 November.

Cedervall Lauta, K. (2016), "Human rights and natural disasters", in Breau, S. and Samuel, K. (Eds.), Research Handbook on Disasters and International Law, Edward Elgar, Cheltenham, UK), pp. 91-110.

Charter of the United Nations (adopted 26 June 1945, entered into force 24 October 1945).

Convention on the Elimination of All Forms of Discrimination against Women (adopted 18 December 1979, entered into force 3 September 1981).

Convention on the Rights of the Child (adopted 20 November 1989, entered into force 2 September 1990).

Convention on the Rights of Persons with Disabilities (opened for signature 13 December 2006, entered into force 3 May 2008). 
Cubie, D. (2014) "Promoting Dignity for All: Human Rights Approaches in the Post2015 Climate Change, Disaster Risk Reduction and Sustainable Development Frameworks", Human Rights and International Legal Discourse, Vol. 8 No. 1, pp. $36-51$.

Cubie, D. and Hesselman, M. (2015) "Accountability for the human rights implications of natural disasters: a proposal for systemic international oversight", Netherlands Quarterly of Human Rights, Vol 33 No. 1, pp. 9-41.

da Costa, K. and Pospieszna, P. (2015), “The Relationship between Human Rights and Disaster Risk Reduction Revisited: Bringing the Legal Perspective into the Discussion", Journal of International Humanitarian Legal Studies Vol. 6, pp. 64-86.

de Albuquerque, C. (2009), "Promotion and Protection of All Human Rights, Civil, Political, Economic, Social and Cultural Rights, Including the Right to Development", UN Doc. A/HRC/12/24 (Report by the Independent Expert on the Issue of Human Rights Obligations Related to Access to Safe Drinking Water and Sanitation).

Ellis, K. and Feris, L. (2014) "The Right to Sanitation: Time to Delink from the Right to Water”, Human Rights Quarterly, Vol. 36 No. 3, pp. 607-29.

European Convention for the Protection of Human Rights and Fundamental Freedoms (adopted 4 November 1950, entered into force 3 September 1953).

Freedman, R. (2014) "UN Immunity or Impunity: A Human Rights Based Challenge”, European Journal of International Law, Vol. 25, pp. 239-254.

Freedman, R. and Lemay-Heber, N. (2015) "Towards an alternative interpretation of UN immunity: A human rights-based approach to the Haiti Cholera Case", Questions of International Law, Vol. 19, pp. 5-18.

Gabc ikovo-Nagymaros Project (Hungary v Slovakia), ICJ Rep 1997, 7 (ICJ, 25 September 1997).

Georges v United Nations (2016) No. 15-455-cv (2d Cir., 18 August 2016)

Guidelines for the Domestic Facilitation and Regulation of International Disaster and Initial Recovery Assistance (2007), 30IC/07/R4 annex.

Heller, L. (2015), "Report of the Special rapporteur on the human right to safe drinking water and sanitation", UN Doc. A/70/203.

Inter Agency Standing Committee (2011), "IASC Operational Guidelines on the Protection of Persons in Situations of Natural Disasters", The Brookings - Bern Project on Internal Displacement.

International Covenant on Civil and Political Rights (opened for signature 16 December 1966, entered into force 23 March 1976). 
International Covenant on Economic, Social and Cultural Rights (adopted 16 December 1966, entered into force 3 January 1976).

Kälin, W. (2011), “A Human Rights-Based Approach to Building Resilience to Natural Disasters", paper presented at the Nansen Conference on Climate Change and Displacement in the 21st Century, 5-7 June, Oslo, Norway, available at: http://www.brookings.edu/research/papers/2011/06/ 06-disasters-human-rights-kaelin (accessed 27 October 2016).

Katz, J. (2013), The Big Truck That Went By: How the World Came to Save Haiti and Left Behind a Disaster, Palgrave Macmillan, New York, US.

LaVenture, et al. $v$ United Nations, et al. (2017) CASE No.: 1:14-cv-01611-SLTRLM (Memorandum of law, request for oral argument) (E.D.N.Y, 23 June 2017)

Narang, S. (2016), "One year after the Nepal earthquake, clean water is still in short supply", UN Dispatch, available at: http://www.undispatch.com/one-year-after-thenepal-earthquake-clean-water-is-still-in-short-supply/ (accessed 27 October 2016).

New Delhi Statement: Global Consultation on Safe Water and Sanitation, UN Doc. A/C.2/45/3 (11 October 1990).

Öneryildiz v Turkey (2005) 41 EHRR 20 (ECtHR, 30 November 2004).

Phan, H. L. and Winkler I. T., "Water Security", in Breau, S. and Samuel, K. (Eds.), Research Handbook on Disasters and International Law, Edward Elgar, Cheltenham, UK), pp. 295-318.

Plan of Implementation of the World Summit on Sustainable Development. UN Doc. A/CONF.199/20, Res. 2, Annex (4 September 2002).

Report of the United Nations Water Conference. UN Doc. E/CONF/70/29 (March 1977).

Rio Declaration on Environment and Development. UN Doc. A/Conf.151/26, Vol I, Annex 1 (12 August 1992).

Sidder, A. (2016), "How Cholera Spread So Quickly Through Haiti",

National Geographic, available at: http://news.nationalgeographic.com/2016/08/haiticholera-crisis-united-nations-admission/ (accessed 2 February 2017).

Sphere Project (2011), "Sphere Handbook: Humanitarian Charter and Minimum Standards in Disaster Response", available at: http://www.sphereproject.org/handbook/ (accessed 30 July 2017).

Stockholm Declaration on the Human Environment, UN Doc. A/Conf.48/14/Rev. 1 (16 June 1972). 
UN (2015), "The Millennium Development Goals Report 2015”, available at: http://www.un.org/millenniumgoals/2015_MDG_Report/pdf/MDG\%202015\%20rev \%20(July\%201).pdf (accessed 30 July 2017).

UN (2016), “UN's Ban apologizes to people of Haiti, outlines new plan to fight cholera epidemic and help communities", 1 December, available at: http://www.un.org/apps/news/story.asp?NewsID=55694\#.WTKXeBPyto4 (accessed 30 July 2017).

UN General Assembly (2000), “The Right to Development”, UN Doc. A/RES54/175, 15 February.

UN General Assembly (1980), "Proclamation of the International Drinking Water Supply and Sanitation Decade", UN Doc A/RES/35/18, 10 November.

UN General Assembly (1991), "Strengthening of the coordination of humanitarian emergency assistance of the United Nations", UN Doc. A/RES/46/182, 19 December.

UN General Assembly (2010), "The Human Right to Water and Sanitation", UN Doc. A/64/292, 28 July.

UN General Assembly, Legal - Sixth Committee (2016), Seventy-first session (3 October-11 November), Agenda item 78.

UN General Assembly (2016), “The human rights to safe drinking water and sanitation”, UN Doc. A/RES/70/169, 22 February.

UN Human Rights Committee (2004), "General comment no. 31: The nature of the general legal obligation imposed on States Parties to the Covenant", UN Doc. CCPR/C/21/Rev.1/Add.13, 26 May.

UN Human Rights Council (2015), "Final research-based report of the Human Rights Council Advisory Committee on best practices and main challenges in the promotion and protection of human rights in post-disaster and post-conflict situations", UN Doc. A/HRC/28/76, 10 February.

UN Children's Fund (2015) (I), "How WASH relates to health, education and development", available at:

http://www.unicef.org/wash/index_healthandeducation.html (accessed 30 July 2017).

UN Children's Fund (2015) (II), “Nepal's Sanitation Social movement Resumes as Post Disaster Recovery Continues", available at: http://unicef.org.np/mediacentre/press-releases/2015/06/13/nepal-s-sanitation-social-movement-resumes-aspost-disaster-recovery-continues (accessed 30 July 2017).

UN Children's Fund, Plan International, Save the Children, Terres des Hommes and World Vision (2016), "Children's Voices, Children's Rights: One Year After The Nepal Earthquake", available at: http://unicef.org.np/uploads/files/571551986548225767-children-s-voices-children-srights-full-report.pdf (accessed 30 July 2017). 
UN-Water (2013), Factsheet on Water Quality, available at:

http://www.unwater.org/fileadmin/user_upload/unwater_new/docs/water_quality.pdf (accessed 30 July 2017).

Valencia-Ospina, E. (2013), "Sixth report on the protection of persons in the event of disasters”, UN Doc. A /CN.4/662, 3 May.

Villagran Morales et al v Guatemala (IACtHR, 19 November 1999).

World Health Organization (2015), "Sanitation", available at http://www.who.int/mediacentre/factsheets/fs392/en/ (accessed 30 July 2017).

World Health Organization, United Nations Children's Fund, Water Supply and Sanitation Collaborative Council (2008), "10 Things You Need to Know About Sanitation".

Winkler, I. (2016), “The Human Right to Sanitation”, University of Pennsylvania Journal of International Law, Vol. 37, pp. 1331-1406.

Winkler, I. (2012), The Human Right to Water: Significance, Legal Status and Implications for Water Allocation, Hart, Oxford, UK.

Zimmer, A., Winkler, I. and de Albuquerque, C. (2014), "Governing Wastewater, Curbing Pollution, and Improving Water Quality for the Realization of Human Rights", Waterlines, Vol. 33, pp. 337-356. 